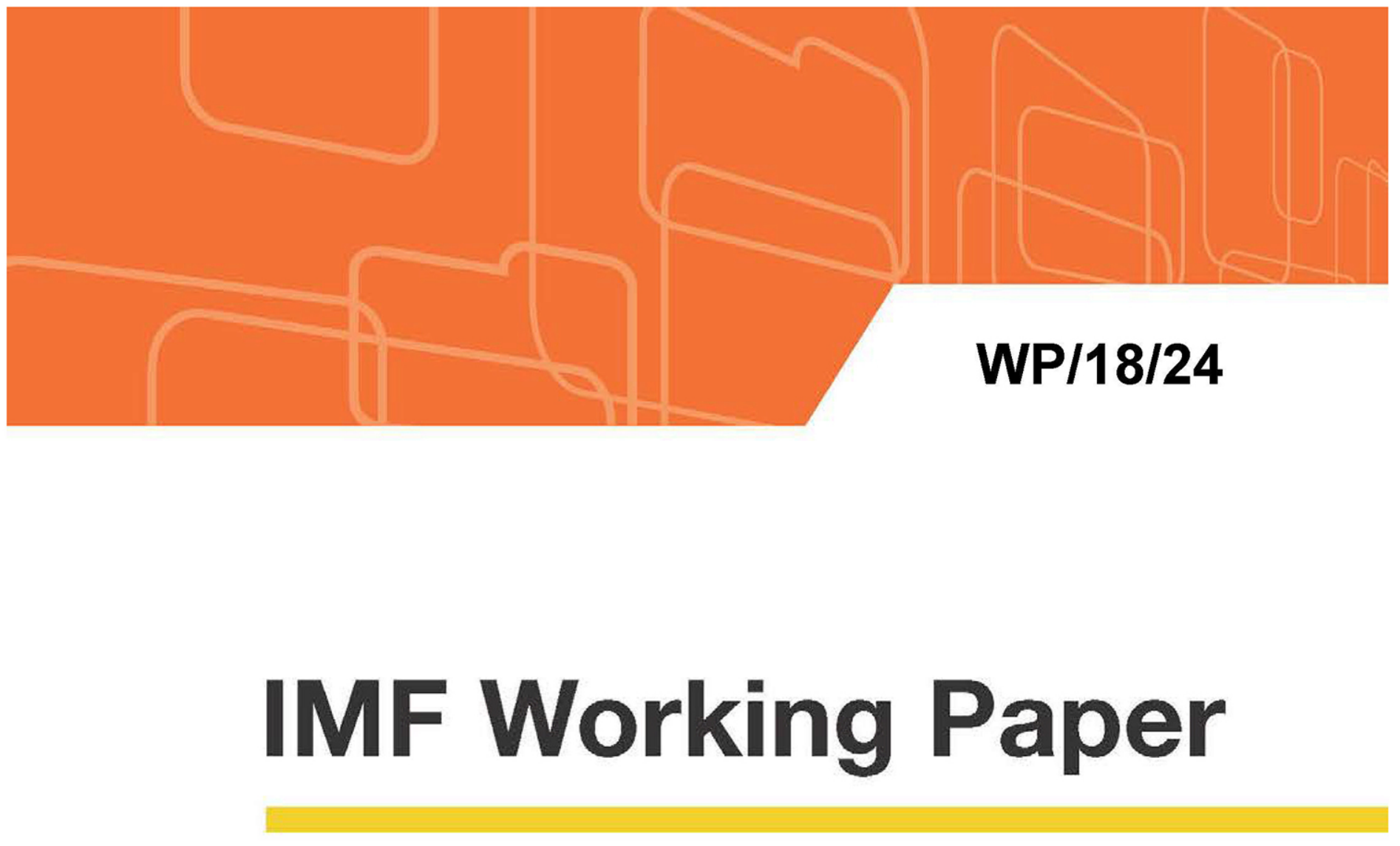

\title{
Disagreement about Future Inflation: Understanding the Benefits of Inflation Targeting and Transparency
}

by Steve Brito, Yan Carrière-Swallow, and Bertrand Gruss

IMF Working Papers describe research in progress by the author(s) and are published to elicit comments and to encourage debate. The views expressed in IMF Working Papers are those of the author(s) and do not necessarily represent the views of the IMF, its Executive Board, or IMF management. 


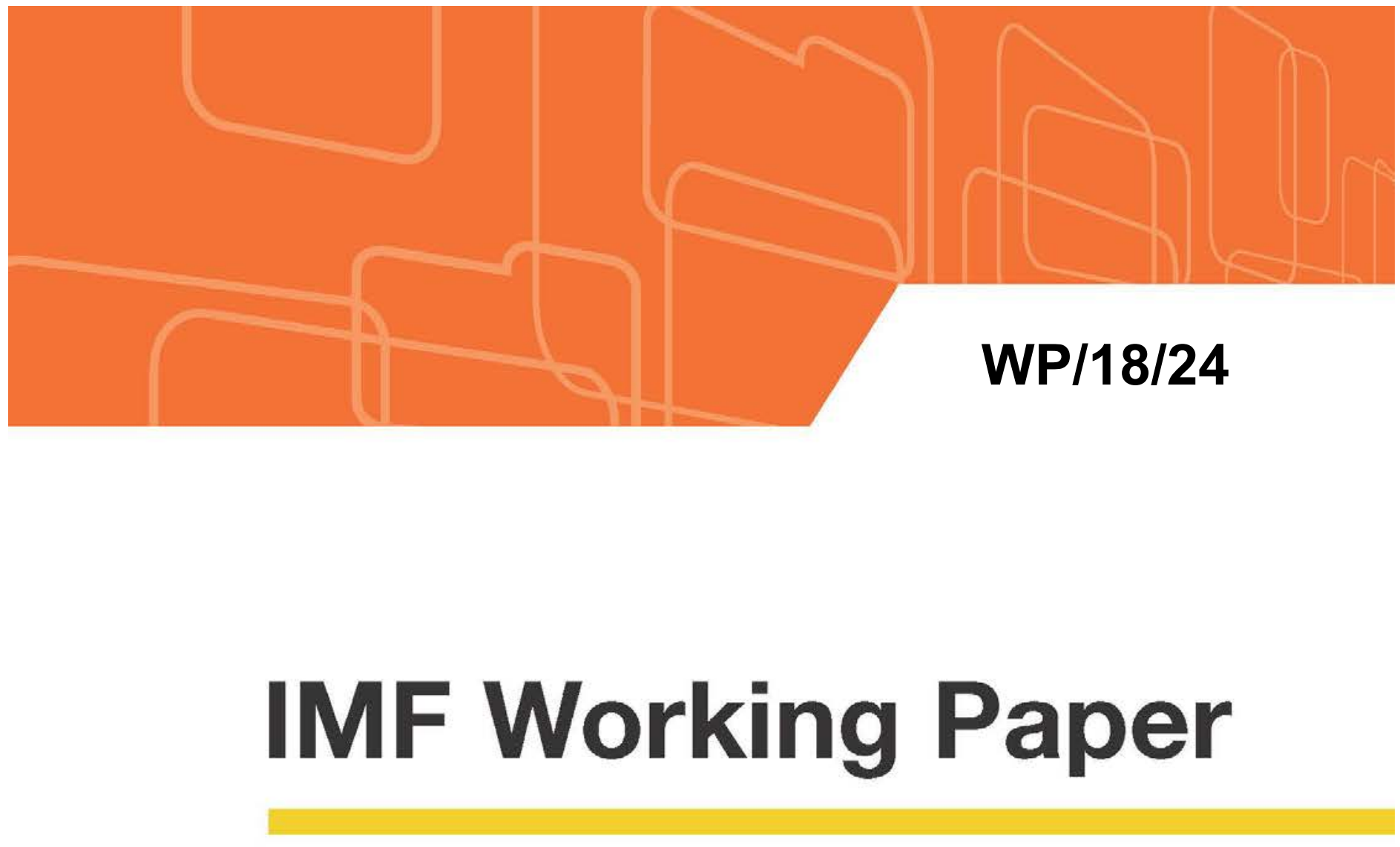

\section{Disagreement about Future Inflation: Understanding the Benefits of Inflation Targeting and Transparency}

by Steve Brito, Yan Carrière-Swallow, and Bertrand Gruss

IMF Working Papers describe research in progress by the author(s) and are published to elicit comments and to encourage debate. The views expressed in IMF Working Papers are those of the author(s) and do not necessarily represent the views of the IMF, its Executive Board, or IMF management.

$$
\text { I N T E R N A T I O N A L M O N E T A R Y F U N D }
$$




\title{
IMF Working Paper
}

Western Hemisphere Department

\section{Disagreement about Future Inflation: Understanding the Benefits of Inflation Targeting and Transparency}

\author{
Prepared by Steve Brito, Yan Carrière-Swallow, and Bertrand Gruss
}

Authorized for distribution by Hamid Faruqee

January 2018

\section{IMF Working Papers describe research in progress by the author(s) and are published to elicit comments and to encourage debate. The views expressed in IMF Working Papers are those of the author(s) and do not necessarily represent the views of the IMF, its Executive Board, or IMF management.}

\begin{abstract}
We estimate the determinants of disagreement about future inflation in a large and diverse sample of countries, focusing on the role of monetary policy frameworks. We offer novel insights that allow us to reconcile mixed findings in the literature on the benefits of inflation targeting regimes and central bank transparency. The reduction in disagreement that follows the adoption of inflation targeting is entirely due to increased central bank transparency. Since the benefits of increased transparency are non-linear, the gains from inflation targeting adoption have accrued mainly to countries that started from a low level of transparency. These have tended to be developing countries.

JEL Classification Numbers: E52, E58, C53.

Keywords: Inflation targeting, central bank transparency, inflation forecasts.

Author's E-Mail Address: SBrito@imf.org; YCSwallow@,imf.org; BGruss@imf.org

\footnotetext{
'We thank Andrés Fernández, Davide Furceri, Carlos Gonçalves, Douglas Laxton, Eduardo Levy-Yeyati, Michael Pedersen, Klaus Schmidt-Hebbel, and seminar participants at the IMF Research Department, LACEA Annual Meetings in Buenos Aires, and the Inter-American Development Bank for their thoughtful comments.
} 


\section{INTRODUCTION}

The extent to which economic agents agree or disagree about the future path of inflation has become the subject of a growing theoretical and empirical literature. This interest in disagreement and its determinants is motivated by two arguments. First, disagreement about the future may lead to misallocation of resources and impose welfare costs, as is the case in models that deviate from the assumption of full-information rational expectations, such as those that feature sticky (Mankiw \& Reis, 2002) or noisy information (Sims, 2003). Second, disagreement about future inflation is thought to provide a proxy for the degree to which inflation expectations are well anchored, and is thus important for the conduct of monetary policy. ${ }^{1}$

Our paper provides an empirical exploration of the determinants of disagreement about future inflation among professional forecasters. Following Capistrán \& Ramos-Francia (2010) and Dovern, Fritsche \& Slacacek (2012), we rely on information reported by Consensus Economics surveys, but expand the sample substantially to cover a larger number of economies (44 in total, half of which are developing economies) and a substantial period after the Global Financial Crisis. In this larger sample, we confirm many of the findings from the literature: disagreement about future inflation: (i) increases in the level and volatility of inflation, and (ii) is counter-cyclical with respect to output, spiking during recessions. We also document that disagreement increases with global uncertainty, proxied by the VIX index.

We then ask whether two aspects of monetary policymaking - namely the adoption of inflation targeting (IT) regimes and increased central bank transparency_also affect disagreement among professional forecasters, and thus the anchor of inflation expectations. Large literatures have studied the gains from IT adoption and increased central bank transparency in terms of delivering price stability and anchoring expectations, yielding notably mixed and samplespecific results. This work has generally concluded that significant gains from IT adoption have been limited to developing economies, with studies on advanced economies usually yielding very small or nil effects. ${ }^{2}$ While existing work on transparency has generally focused on advanced economies, there too evidence has been mixed, with even the sign of its impact on disagreement varying across studies. ${ }^{3}$

\footnotetext{
${ }^{1}$ See, for instance, the arguments presented in Capistrán \& Ramos-Francia (2010), Dovern, Fritsche \& Slacacek (2012), Ehrmann (2015), and Kumar, Afrouzi, Coibion \& Gorodnichenko (2015).

${ }^{2}$ See, for instance, Johnson (2002), Ball \& Sheridan (2004) and Gürkaynak, Levin, and Swanson (2010) for studies on advanced economies, and Vega \& Winkelried (2005), Gonçalves \& Salles (2008), Brito \& Bystedt (2010), Crowe (2010) and Capistrán \& Ramos-Francia (2010) for studies that include developing economies. ${ }^{3}$ In samples of advanced economies, Siklos (2013) finds that increasing transparency increased forecast disagreement, whereas Ehrmann, Eiffinger \& Fratscher (2012) find that the relationship is negative but exhibits diminishing returns. Crowe \& Meade (2008) consider a sample that includes both advanced and developing economies, finding evidence that increasing transparency improved the accuracy of private sector forecasts.
} 
The added variation in our sample enables us to estimate the effects of these related treatments - the adoption of IT and increased central bank transparency - jointly, allowing us to reconcile the mixed evidence in previous studies. We start by confirming Capistrán \& Ramos-Francia's (2010) finding that disagreement falls following IT adoption, but only in developing economies. We then provide three novel results:

First, we show that the distinction between advanced and developing economies also applies to the impact of transparency on disagreement. Increased transparency has indeed reduced disagreement, but these benefits have only accrued among developing economies.

Second, the gains that follow the adoption of IT regimes can be entirely accounted for by the effect of increased transparency. That is, for a given level of transparency, IT adoption has no marginal effect on forecast disagreement in advanced or developing countries.

Finally, the effect of transparency on disagreement is sufficiently non-linear to explain why the gains from IT adoption have been so sample-specific in the literature. Developing economies have tended to adopt inflation targeting from a much lower initial level of central bank transparency than their advanced economy counterparts. We show that this can account for why gains from IT adoption have been much stronger in samples of developing economies than in those that focus on advanced economies, where null results have been common in the literature.

An implication of our results is that the adoption of inflation targeting should not be considered a binary treatment in empirical studies. To the extent that adoption (i) is accompanied by reforms to the way policy is undertaken-namely, through increased transparency, and (ii) takes place from a low starting level of transparency, gains have indeed been substantial. However, in those cases where IT adoption has involved only the announcement of a numerical target, or when it has been adopted by central banks that already operate highly transparent frameworks, gains have been limited.

The paper is organized as follows. In section II, we discuss the data and present summary statistics about our measure of disagreement. In section III, we present our empirical model of inflation forecast disagreement and discuss the results of our estimations. Section IV concludes and draws implications.

\section{DATA}

Our measure of inflation forecast disagreement is based on surveys of professional forecasters collected by Consensus Economics. The countries included in the sample are listed in Table 1, and its cross-sectional size is plotted over time in Figure 1. The survey began covering the G7 economies in October 1989, and the sample has since grown 
substantially since then. While subsets of this data have been employed in previous studies, this paper makes use of a considerably expanded panel, with responses from individual forecasters covering up to 44 economies from October 1989 to December $2016 .{ }^{4}$

Each month, Consensus Economics collects forecasts from professional forecasters for their expected rate of inflation for the current and following calendar years. Since the forecast horizon shrinks over the calendar year, disagreement about inflation is expected to decline as the common information set grows relative to the forecast horizon.

Two strategies have been adopted in the literature to deal with the seasonal pattern displayed by the cross-sectional dispersion of these fixed-event forecasts. The first is to include month fixed effects in regression analysis. ${ }^{5}$ It is not clear that this provides sufficient treatment for seasonality in a panel setting, however, since the rate of information release may differ across countries. A second strategy, which we follow here, is to construct a synthetic fixed-horizon forecast as a weighted average of the fixed-event forecasts. ${ }^{6}$

The one-year-ahead synthetic fixed-horizon forecast is constructed as the weighted average of the forecasts for the current $\left(\hat{X}_{t+k \mid t}\right)$ and next calendar year $\left(\widehat{X}_{t+12+k \mid t}\right)$, with weights that vary according to the date the forecast was produced:

$$
\tilde{X}_{t+12 \mid t}=\frac{k}{12} \hat{X}_{t+k \mid t}+\frac{12-k}{12} \hat{X}_{t+12+k \mid t}
$$

where $k$ is the months remaining in the year at the time the forecast was produced $(k \in\{1,2, \ldots, 12\})$ at period $t$.

Following Mankiw, Reis, and Wolfers (2004), we measure inflation forecast disagreement, $D_{i, t}$, as the interquartile range across individual synthetic fixed-horizon forecasts for country $i$ in month $t .{ }^{7}$ Figure 2 plots the empirical distribution of $D_{i, t}$ in our full sample. Disagreement is widespread in our sample: for the median country-month, the interquartile range across individual forecasts is 0.38 .

\footnotetext{
${ }^{4}$ While more countries are included in the surveys, our focus on disagreement leads us to limit our study to the sample of 45 economies for which forecaster-level information is made available. We further exclude Taiwan, POC, because it is not covered by the Dincer \& Eichengreen (2014) index of central bank transparency.

5 This strategy is employed by Ehrmann, Eijffinger, and Fratzscher (2010) and Capistrán and Ramos-Francia (2010), amongst others.

${ }^{6}$ This strategy is employed by Mankiw, Reis, and Wolfers (2004); Dovern, Fritsche, and Slacalek (2012); Siklos (2013); and Ozturk and Sheng (2017). Results available upon request show that our main findings are robust to adopting the first strategy.

${ }^{7}$ Another common approach is to use the standard deviation across forecasts as a measure of forecast disagreement (see, for instance, Johnson, 2002; Coibion and Gorodnichenko, 2012; Siklos, 2013), but this approach is more vulnerable to extreme forecasts. All results presented below are robust to the use of this alternative definition of disagreement, and are available upon request.
} 
Table 1. Sample of economies

A. Advanced economies

\begin{tabular}{llll}
\hline \multicolumn{2}{c}{ Inflation targeters } & \multicolumn{2}{c}{ Others } \\
\hline Australia (Mar. 93-) & Spain (Jan. 95-99) & Estonia & Netherlands \\
Canada (Feb. 91-) & South Korea (Apr. 98-) & France & Singapore \\
Czech Republic (Dec. 97-) & Sweden (Jan. 93-) & Germany & Slovakia \\
Japan (Feb. 13-) & Switzerland (Jan. 00-) & Hong Kong, SAR & Slovenia \\
New Zealand (Mar. 90-) & United Kingdom (Oct. 92-) & Italy & \\
Norway (Mar. 01-) & United States (Jan. 12-) & Latvia & \\
\hline
\end{tabular}

B. Developing economies

\begin{tabular}{llll}
\hline & Inflation targeters & \multicolumn{2}{c}{ Others } \\
\hline Brazil (Jul. 99-) & Peru (Jan. 02-) & Argentina & Venezuela \\
Chile (Sept. 99-) & Philippines (Jan. 02-) & Bulgaria & \\
Colombia (Sept. 99-) & Poland (Sept. 98-) & China & \\
Hungary (Jun. 01-) & Romania (Aug. 05-) & Croatia & \\
India (Feb. 15-) & Russia (Jan. 15-) & Lithuania & \\
Indonesia (Jul. 05-) & Thailand (Jan. 00-) & Malaysia & \\
Mexico (Feb. 01-) & Turkey (Jan. 06-) & Ukraine & \\
\hline
\end{tabular}

Note: Income classifications are as of January 2015. Date of IT adoption in parentheses. Total $\mathrm{AE}=22$; total $\mathrm{EMDE}=22$.

Figure 1: Number of countries by income group and monetary policy regime

A. Full sample

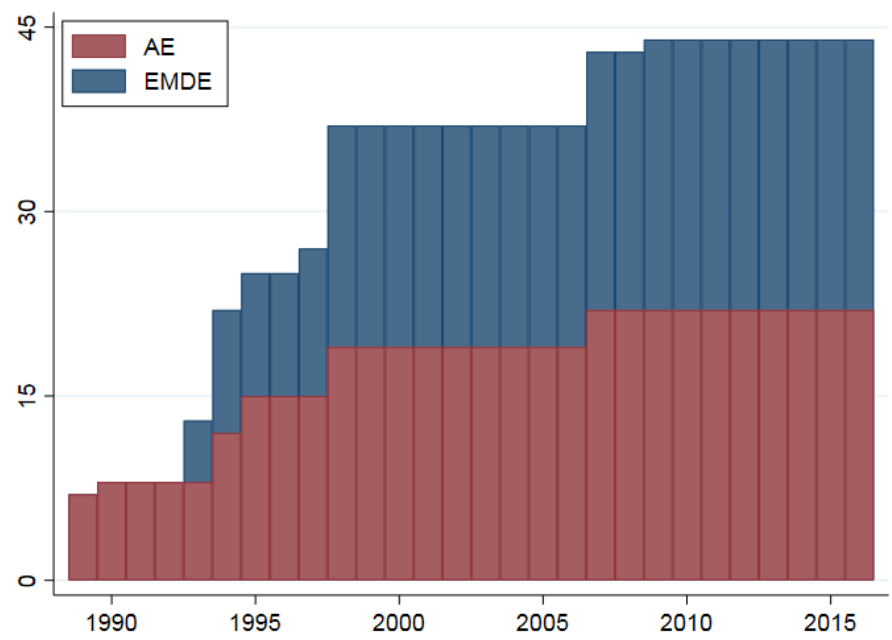

B. Inflation targeters

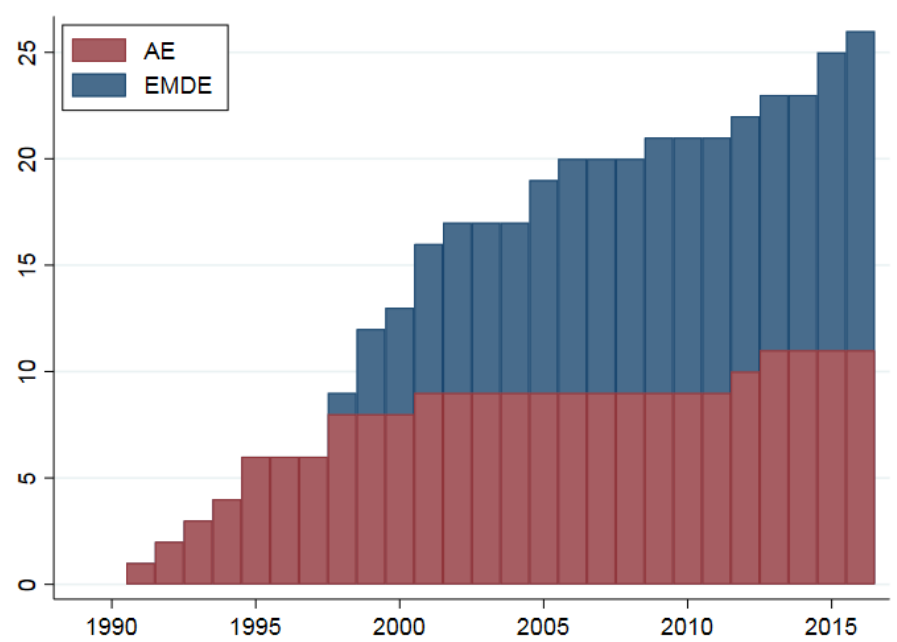

Source: Authors' calculations based on data from Consensus Economics. 
Figure 2: Histogram of disagreement about inflation one year ahead

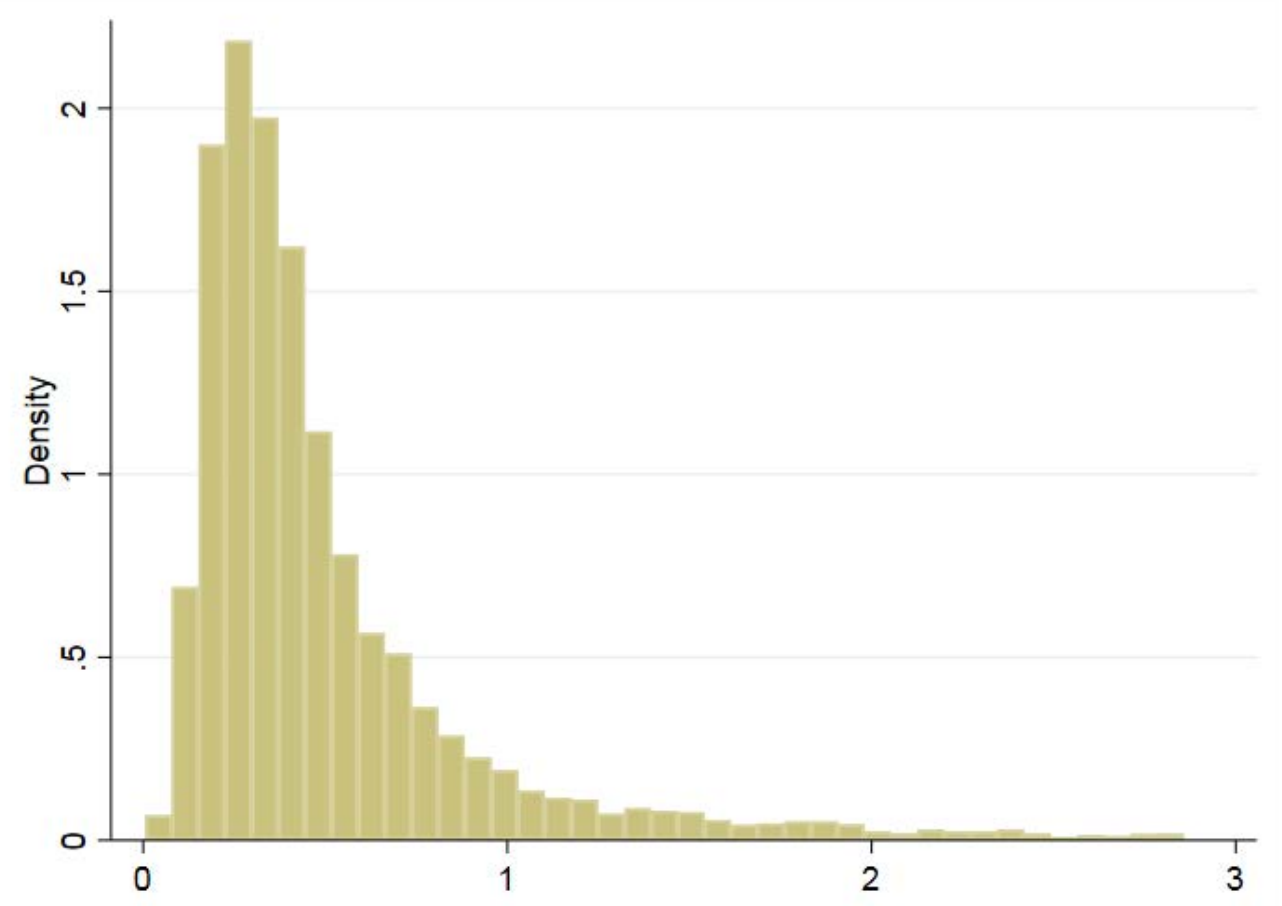

Source: Authors' calculations based on data from Consensus Economics. For presentation only, data are shown up to the $96^{\text {th }}$ percentile of the full sample.

The distribution of disagreement is skewed to the left, with a small number of very large values of disagreement. Upon inspection, we note that these extreme values correspond to severe economic crises in developing economies. To avoid swaying estimation results based on a handful of outliers, we truncate the sample at the $99^{\text {th }}$ percentile of disagreement (where $D_{i, t}=$ 9.9), thus discarding 100 observations. These excluded data correspond to periods of instability in Argentina, Brazil, Indonesia, Russia, Turkey, Ukraine, and Venezuela, during which the annual inflation rate averaged 332 percent, with a range of -34 to almost 5,000 percent.

Disagreement in the trimmed sample still contains substantial heterogeneity and remains somewhat skewed to the left, ranging from 0.1 to 9.9 percentage points, with a mean of 0.65 and a standard deviation of 0.97 percentage points. These values differ across income groups, with advanced economies (AE) displaying median disagreement of 0.30 , compared to 0.56 in emerging market and developing economies (EMDE). Disagreement in the latter group is also more volatile, with a standard deviation of 1.36 versus only 0.26 in AEs.

Figure 3 plots the evolution of disagreement about inflation by income group, taking medians across countries for each month. Two observations stand out. First, the degree of disagreement has tended to be higher for developing economies than for advanced economies. Second, the gap in disagreement among these groups has decreased significantly 
Figure 3: Disagreement about inflation one year ahead, by income group

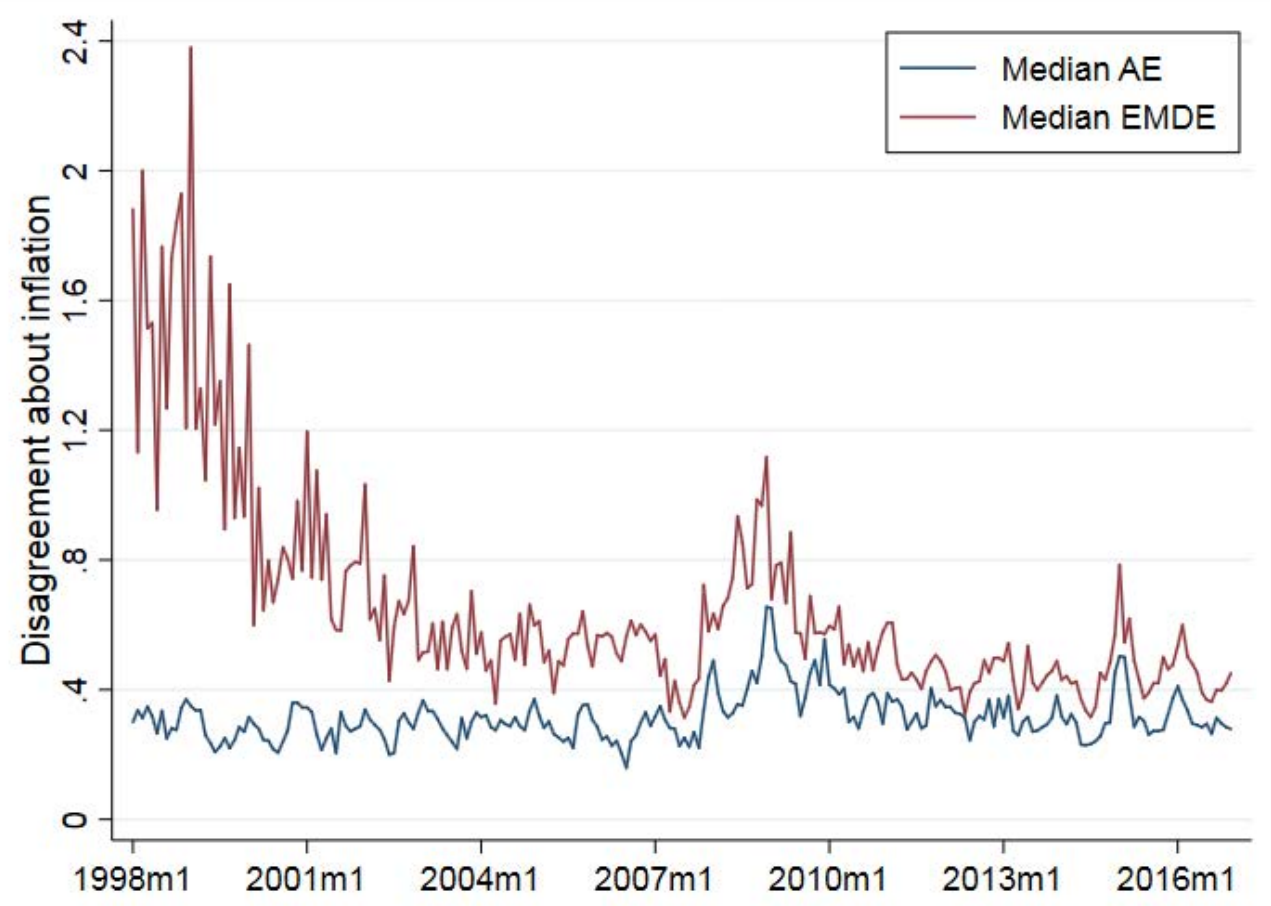

Source: Authors' calculations based on data from Consensus Economics. Figure reports median disagreement across countries, by income group.

over time, and this convergence almost exclusively reflects the steady reduction of disagreement in developing economies.

\section{AN EMPIRICAL MODEL OF DISAGREEMENT ABOUT INFLATION}

In line with Capistrán and Ramos-Francia (2010), Dovern, Fritsche, and Slacalek (2012), and Ehrmann, Eijffinger, and Fratzscher (2012), we estimate a panel model of inflation forecast disagreement one year ahead:

$$
D_{i, t}=\boldsymbol{\alpha}_{i}+\beta \boldsymbol{X}_{i, t}+\gamma \boldsymbol{X}_{t}^{*}+\varepsilon_{i, t},
$$

where $\boldsymbol{\alpha}_{i}$ is a set of country fixed effects. The vector of country-specific explanatory variables $\boldsymbol{X}_{i, t}$ is based on the empirical literature on the determinants of inflation forecast disagreement. Mankiw, Reis and Wolfers (2004) found that, in the United States, disagreement about future inflation is proportional to the level of realized inflation. We include the year-over-year change in the Consumer Price Index (CPI), obtained from the IMF International Financial Statistics database (IFS). 
In their research on G7 economies, Dovern, Fritsche, and Slacalek (2012) find that disagreement about future inflation is proportional to the variability of the shocks that hit the economy. We follow their approach, estimating the unobserved component stochastic volatility model proposed by Stock and Watson (2007) to estimate the time-varying volatility of inflation. Specifically, the model decomposes inflation $\pi_{t}$ into a permanent component $p_{t}$ and a transitory component $\tau_{t}\left(\pi_{t}=p_{t}+\tau_{t}\right)$; where white noise innovations $\varepsilon_{t}$ affect the permanent component $\left(p_{t}=p_{t-1}+\varepsilon_{t}\right)$. We include in $\boldsymbol{X}_{i, t}$ the estimated time-varying variance of shocks to the permanent component, $\hat{\sigma}_{\varepsilon}^{2}$.

While Mankiw, Reis and Wolfers (2004) estimate that disagreement about inflation has been acyclical with respect to output in the United States, Dovern, Fritsche, and Slacalek (2012) find that it has been countercyclical in the $\mathrm{G} 7$ economies, and has spiked during recessions. As a measure of economic slack, we include in $\boldsymbol{X}_{i, t}$ an estimate of the output gap. ${ }^{7}$ To allow for a non-linear effect of large negative shocks, we also include a recession dummy when year-overyear growth is negative for two consecutive quarters. ${ }^{8}$

We also include a limited number of common external variables in the vector $\boldsymbol{X}_{t}^{*}$. Following Capistrán and Ramos-Francia (2010), we include a measure of global inflation, which they find to lead to increased disagreement in a large sample of countries. In a novel test, and under the familiar rationale that uncertainty about shocks hitting the economy will tend to increase disagreement about the future trajectory of macro variables - including inflation - we include the VIX index as a measure of external uncertainty in $\boldsymbol{X}_{t}^{*}$. As a robustness check, reported in Appendix Table A1, we remove the vector $\boldsymbol{X}_{t}^{*}$ and replace it with a full vector of monthly time fixed effects to control for unspecified common shocks to disagreement.

Table 2, column 1 reports the results of our estimation of this model using the full sample of monthly data from October 1989 through December 2016. To ease the interpretation of coefficients, we have expressed the disagreement variable in basis points of inflation. The results confirm many stylized facts that have been documented in the existing literature: (i) disagreement about inflation rises with the level of inflation, (ii) rises with the volatility of inflation, though the relationship is not statistically significant in all specifications, (iii) is countercyclical with respect to output, ${ }^{9}$ (iv) and rises sharply during recessions.

\footnotetext{
${ }^{7}$ We estimate the output gap by applying the Hodrick-Prescott (HP) filter with a smoothing parameter of 1,600 to each country's quarterly real GDP series from the IMF's International Financial Statistics database.

${ }^{8}$ The monthly recession dummy takes a value of one in every month of a recessionary quarter, and zero otherwise. In our estimation sample, the frequency of recessions is about $11 \%$.

${ }^{9}$ Interestingly, the countercyclicality of disagreement with respect to output depends on using a two-sided HP filter to estimate the output gap, as we have done in our baseline specification in line with the literature (see, for instance, Dovern, Fritsche and Slacalek, 2012). When we re-estimate the output gap recursively in order to approximate the information set available at the time the forecast was made, the magnitude of this coefficient shrinks considerably and becomes statistically indistinguishable from zero. All other coefficients remain largely unaffected.
} 
For a given level of domestic inflation, global inflation does not seem to have an additional effect on disagreement. Finally, we find the novel result that disagreement about inflation rises sharply with global uncertainty. The strength of this relationship is large: during the Global Financial Crisis, the VIX index rose suddenly from 25 to over 60, and our estimates imply that this move would raise disagreement about inflation by around 17 basis points on average.

Does the adoption of an IT regime anchor inflation expectations?

We augment equation (1) with a dummy variable indicating the adoption of an inflation targeting regime:

$$
D_{i, t}=\boldsymbol{\alpha}_{i}+\beta \boldsymbol{X}_{i, t}+\gamma \boldsymbol{X}_{t}^{*}+\delta I[\text { IT regime }]_{i, t-12}+\varepsilon_{i, t},
$$

where $I$ [IT regime $]_{i, t}$ is a dummy variable that is equal to one when a country operates an inflation targeting regime, and zero otherwise. ${ }^{10}$ The treatment variable has been lagged one year in order to mitigate endogeneity in the relationship between disagreement and the adoption of an IT regime. Table 2, column 2 reports the results of estimating equation 2 . On average, countries operating an IT regime display lower disagreement than those that operate other monetary policy frameworks.

Gonçalves and Salles (2008) argue that the gains from IT adoption in terms of price stability are strongest among developing economies, in contrast to earlier null results that had been based on the experience of advanced economies. In column 3, we add an interaction term between IT adoption and an EMDE dummy, replicating a result documented by Capistrán and Ramos-Francia (2010): the reduction in disagreement from IT adoption accrues exclusively to developing economies, where the marginal impact is larger than in the full sample, with no impact among advanced economies. ${ }^{11}$

\footnotetext{
${ }^{10}$ Inflation targeting adoption dates indicated in Table 1 are based on Capistrán and Ramos-Francia (2010), which we have updated and expanded with information from central bank websites.

11 Table 2, column 4 is included for completeness, to ensure that the results discussed so far are consistent when the sample period is restricted to the coverage of the Dincer \& Eichengreen (2014) index, which will limit the sample used in columns 5 through 10.
} 
Table 2. Estimates for the determinants of disagreement about inflation one year ahead

\begin{tabular}{|c|c|c|c|c|c|c|c|c|c|c|}
\hline & $(1)$ & $(2)$ & (3) & (4) & $(5)$ & $(6)$ & $(7)$ & $(8)$ & (9) & $(10)$ \\
\hline Inflation rate & $\begin{array}{c}5.77 * * * \\
(0.76)\end{array}$ & $\begin{array}{c}5.58 * * * \\
(0.75)\end{array}$ & $\begin{array}{c}5.41 * * * \\
(0.76)\end{array}$ & $\begin{array}{c}4.18^{* * *} \\
(0.55)\end{array}$ & $\begin{array}{c}4.30^{* * *} \\
(0.81)\end{array}$ & $\begin{array}{c}4.20^{* * *} \\
(0.80)\end{array}$ & $\begin{array}{c}4.32 * * * \\
(0.75)\end{array}$ & $\begin{array}{c}7.05 * * * \\
(2.17)\end{array}$ & $\begin{array}{c}4.32 * * * \\
(0.76)\end{array}$ & $\begin{array}{c}3.88^{* * *} \\
(0.60)\end{array}$ \\
\hline Volatility of inflation & $\begin{array}{c}2.43 \\
(1.57)\end{array}$ & $\begin{array}{c}2.43 \\
(1.55)\end{array}$ & $\begin{array}{c}2.41 \\
(1.53)\end{array}$ & $\begin{array}{c}9.79^{* * *} \\
(2.06)\end{array}$ & $\begin{array}{c}10.29 * * * \\
(2.11)\end{array}$ & $\begin{array}{c}10.01 * * * \\
(2.16)\end{array}$ & $\begin{array}{c}9.77 * * * \\
(2.12)\end{array}$ & $\begin{array}{c}47.18^{* * *} \\
(3.75)\end{array}$ & $\begin{array}{c}9.77 * * * \\
(2.12)\end{array}$ & $\begin{array}{c}9.77 * * * \\
(2.14)\end{array}$ \\
\hline Output gap & $\begin{array}{c}-4.22 * * * \\
(0.98)\end{array}$ & $\begin{array}{c}-4.28 * * * \\
(1.01)\end{array}$ & $\begin{array}{c}-4.27 * * * \\
(1.02)\end{array}$ & $\begin{array}{c}-3.34 * * \\
(1.51)\end{array}$ & $\begin{array}{c}-3.04 * * \\
(1.36)\end{array}$ & $\begin{array}{c}-3.16^{* *} \\
(1.38)\end{array}$ & $\begin{array}{c}-2.97 * * \\
(1.44)\end{array}$ & $\begin{array}{c}-3.36^{* *} \\
(1.24)\end{array}$ & $\begin{array}{c}-2.97 * * \\
(1.44)\end{array}$ & $\begin{array}{c}-3.94 * * \\
(1.82)\end{array}$ \\
\hline Recession & $\begin{array}{c}14.66^{* * * *} \\
(4.91)\end{array}$ & $\begin{array}{c}13.42 * * * \\
(4.89)\end{array}$ & $\begin{array}{c}14.32 * * * \\
(4.76)\end{array}$ & $\begin{array}{c}12.10^{* * * *} \\
(3.69)\end{array}$ & $\begin{array}{c}11.66^{* * * *} \\
(3.16)\end{array}$ & $\begin{array}{c}11.29 * * * \\
(3.25)\end{array}$ & $\begin{array}{c}10.09 * * * \\
(3.33)\end{array}$ & $\begin{array}{c}7.20 \\
(6.89)\end{array}$ & $\begin{array}{c}10.13 * * * \\
(3.31)\end{array}$ & $\begin{array}{c}10.14^{* * * *} \\
(3.12)\end{array}$ \\
\hline World inflation & $\begin{array}{c}0.17 \\
(0.27)\end{array}$ & $\begin{array}{l}-0.09 \\
(0.22)\end{array}$ & $\begin{array}{c}0.02 \\
(0.25)\end{array}$ & $\begin{array}{c}1.07 \\
(1.50)\end{array}$ & $\begin{array}{l}-1.44 \\
(1.37)\end{array}$ & $\begin{array}{l}-0.95 \\
(1.25)\end{array}$ & $\begin{array}{l}-1.44 \\
(1.35)\end{array}$ & $\begin{array}{l}-5.85 \\
(5.05)\end{array}$ & $\begin{array}{l}-1.42 \\
(1.37)\end{array}$ & $\begin{array}{c}0.51 \\
(1.45)\end{array}$ \\
\hline VIX index & $\begin{array}{c}0.51^{* * * *} \\
(0.19)\end{array}$ & $\begin{array}{c}0.49 * * \\
(0.18)\end{array}$ & $\begin{array}{c}0.49 * * * \\
(0.18)\end{array}$ & $\begin{array}{c}0.46^{* * *} \\
(0.13)\end{array}$ & $\begin{array}{c}0.34 * * * \\
(0.11)\end{array}$ & $\begin{array}{c}0.36^{* * *} \\
(0.10)\end{array}$ & $\begin{array}{c}0.37 * * * \\
(0.10)\end{array}$ & $\begin{array}{l}-0.01 \\
(0.30)\end{array}$ & $\begin{array}{c}0.37 * * * \\
(0.11)\end{array}$ & $\begin{array}{c}0.46^{* * *} \\
(0.13)\end{array}$ \\
\hline IT (12-mth lag) & & $\begin{array}{c}-18.43 * * * \\
(6.48)\end{array}$ & $\begin{array}{l}-1.76 \\
(5.71)\end{array}$ & $\begin{array}{c}4.95 \\
(5.34)\end{array}$ & & & & & $\begin{array}{c}3.77 \\
(7.04)\end{array}$ & \\
\hline IT \& EMDE (12-mth lag) & & & $\begin{array}{c}-31.22^{* * *} \\
(11.41)\end{array}$ & $\begin{array}{c}-28.29 * * * \\
(7.67)\end{array}$ & & & & & $\begin{array}{l}-2.36 \\
(14.50)\end{array}$ & \\
\hline Central bank transparency (12-mth lag) & & & & & $\begin{array}{c}-3.76^{* *} \\
(1.86)\end{array}$ & $\begin{array}{l}-0.10 \\
(0.86)\end{array}$ & $\begin{array}{c}-19.94 * * * \\
(6.73)\end{array}$ & $\begin{array}{c}-45.24 * * \\
(19.32)\end{array}$ & $\begin{array}{c}-20.08 * * \\
(8.00)\end{array}$ & \\
\hline Central bank transparency \& EMDE (12-mth lag) & & & & & & $\begin{array}{c}-6.52 * * \\
(2.88)\end{array}$ & & & & \\
\hline Central bank transparency squared (12-mth lag) & & & & & & & $\begin{array}{c}1.04 * * * \\
(0.35)\end{array}$ & $\begin{array}{c}2.66 * * \\
(1.03)\end{array}$ & $\begin{array}{l}1.04 * * \\
(0.39)\end{array}$ & \\
\hline IT \& Low transparency (12-mth lag) & & & & & & & & & & $\begin{array}{c}-27.50^{* * *} \\
(4.89)\end{array}$ \\
\hline IT \& Mid transparency (12-mth lag) & & & & & & & & & & $\begin{array}{l}-11.57 \\
(10.94)\end{array}$ \\
\hline IT \& High transparency (12-mth lag) & & & & & & & & & & $\begin{array}{c}2.39 \\
(2.90)\end{array}$ \\
\hline Observations & 9,879 & 9,879 & 9,879 & 7,697 & 7,479 & 7,479 & 7,479 & 2,632 & 7,479 & 7,503 \\
\hline R-squared & 0.33 & 0.34 & 0.34 & 0.34 & 0.37 & 0.38 & 0.39 & 0.25 & 0.39 & 0.34 \\
\hline Number of countries & 44 & 44 & 44 & 44 & 44 & 44 & 44 & 17 & 44 & 44 \\
\hline Start & $1989 \mathrm{ml} 0$ & $1989 \mathrm{ml} 0$ & $1989 \mathrm{ml} 0$ & $1999 \mathrm{ml}$ & $1999 \mathrm{ml}$ & 1999ml & $1999 \mathrm{ml}$ & $1999 \mathrm{ml}$ & 1999ml & 1999ml \\
\hline $\begin{array}{l}\text { End } \\
\text { IT countries }\end{array}$ & $2016 \mathrm{ml} 2$ & $2016 \mathrm{ml} 2$ & $2016 \mathrm{ml} 2$ & $2015 \mathrm{ml} 2$ & $2015 \mathrm{ml} 2$ & $2015 \mathrm{ml} 2$ & $2015 \mathrm{ml} 2$ & $\begin{array}{r}2015 \mathrm{ml} 2 \\
\text { Excluded }\end{array}$ & $2015 \mathrm{ml} 2$ & $2015 \mathrm{ml} 2$ \\
\hline
\end{tabular}

Notes: All specifications include country fixed effects. Disagreement variable has been truncated at $99^{\text {th }}$ percentile (see text). White (1980) heteroskedasticityconsistent robust standard errors in parentheses. $* * * \mathrm{p}<0.01, * * \mathrm{p}<0.05, * \mathrm{p}<0.1$. 


\section{Reconciling sample-specific results: What drives gains from IT adoption?}

Why do the gains to IT adoption appear so sample specific, and tend to favor developing economies? Our explanation is based on the argument that IT adoption should not be considered a binary treatment, because it embodies vastly different experiences. The adoption of an IT regime is closely associated with increased central bank transparency. By definition, adoption implies the announcement of a numerical target for inflation. But it can also involve many additional changes to the way monetary policy is conducted. These commonly include the publication of regular reports explaining the plans, objectives, and decisions of the monetary authority, which may include the data and forecasts for key macroeconomic variables underpinning decisions. It can also involve the introduction of a range of communication tools such as statements, meeting minutes, and interviews that reduce the asymmetry of information between policymakers and the public (Mishkin, 2000). The preparation of these products usually requires hiring additional technical staff, and changing the internal processes of the decision-making process.

Many of these aspects of policymaking are captured in the index of central bank transparency constructed by Dincer \& Eichengreen (2014), which takes values between 1 and 15. The index covers five categories that measure political, economic, procedural, policy, and operational aspects of central bank transparency. ${ }^{13}$ Figure 4, Panel A displays the median evolution of central bank transparency surrounding the 15 IT adoption events in our dataset. The median IT adoption involves an increase in transparency of about 3.5 points on the 1-15 scale, but this masks substantial heterogeneity across events. As Panel B shows, there are episodes of IT adoption that involve very large increases in transparency, but others that involve hardly any change. To understand the gains from IT adoption, this heterogeneity must be taken into account.

But does increased central bank transparency anchors expectations by reducing disagreement? Morris and Shin (2002) argue that, in theory, the gains from transparency could go either way, and depend on the relative accuracy of public and private information sources. The empirical literature has produced similarly mixed answers to this question. Ehrmann, Eijffinger \& Fratzscher (2012) study a sample of 12 advanced economies, and find that increased transparency leads to sizeable reductions in disagreement. However, Siklos (2013) studies a subset of these countries and finds that impacts vary substantially across countries, being generally either nil or positive, and thus that more transparency increases disagreement on average.

\footnotetext{
${ }^{13}$ See Appendix 1 in Dincer \& Eichengreen (2014) for details on the components of the index. For instance, political transparency includes "Is there a quantification of the primary objective(s)?", economic transparency includes "Does the central bank disclose the macroeconomic model(s) it uses for policy analysis?", and procedural transparency includes "Does the central bank disclose how each decision on the level of its main operating instrument or target was reached?"
} 
Figure 4. Event study: Central bank transparency surrounding IT adoption episodes
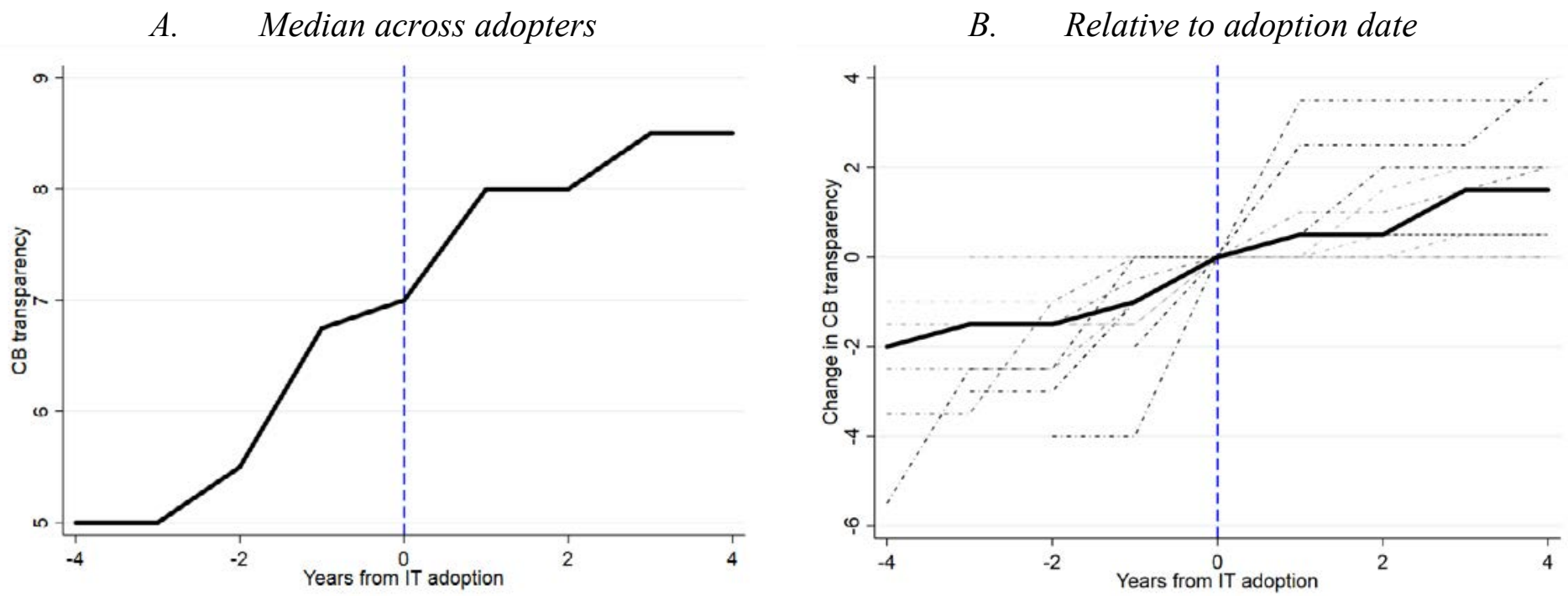

Note: Event study based on 15 episodes of IT adoption between 1998 and 2014, for which data on central bank transparency from Dincer \& Eichengreen (2014) are available for the year of adoption. In panel B, the solid line corresponds to the median across episodes, and dashed lines show each episode coded such that larger increases in transparency have a darker shade.

To test the impact of increased central bank transparency on our more diverse sample of countries, we substitute the index for the IT treatment variable in equation (2):

$$
D_{i, t}=\boldsymbol{\alpha}_{i}+\beta \boldsymbol{X}_{i, t}+\gamma \boldsymbol{X}_{t}^{*}+\varphi T_{i, t-12}+\varepsilon_{i, t}
$$

where $T_{i, t}$ corresponds to the index of central bank transparency from Dincer \& Eichengreen (2014), which we have again lagged by one year to mitigate endogeneity concerns. Results for this specification are reported in Table 2 column 5, where we find an average effect that increasing transparency by 1 point reduces disagreement by almost 4 basis points. In column 6 , we interact $T_{i, t}$ with a dummy variable for developing economies. In line with our results for IT adoption, we find that the impact of increasing transparency on disagreement is strong among EMDEs, with each point on the scale reducing disagreement by 6.5 basis points. Among the 22 advanced economies in our sample, however, the average effect of transparency on disagreement is nil.

Importantly, the benefits from increasing transparency may exhibit diminishing returns (Walsh, 2007). This result has been documented empirically by Ehrmann, Eijffinger \& Fratzscher (2012), and to test for it in our sample we augment equation (3) with a quadratic term, $T_{i, t-12}^{2}$. In our broad sample of countries, the effect of transparency on disagreement is inversely proportional to the level of transparency. For instance, increasing the transparency 
score from 3 to 5 is estimated to reduce disagreement by 25 basis points, while increasing transparency from 8 to 10 points leads to a reduction in disagreement of only 4 basis points. In line with Van der Cruijsen, Eijffinger and Hoogduin (2010), the non-linearity is strong enough that the marginal returns become negative for values of transparency greater than 10 points, suggesting the existence of an optimal degree of transparency. ${ }^{14}$

We have argued that IT adoption and increased transparency are closely related, but that the latter gives a better description of de facto changes to the monetary policy regime. To what extent is transparency sufficient to summarize the gains from IT adoption? We estimate an augmented model that includes both IT adoption and transparency treatment variables, reporting the results in column 9. Note that while the relationship between transparency and disagreement remains unchanged from column 7, the significance of IT adoption in developing economies is indistinguishable from zero. That is to say, IT adoption has lowered disagreement only to the extent that it has involved an increase in central bank transparency. For a given level of transparency, IT adoption has not provided an additional anchor for expectations in either advanced or developing economies.

Taken together, these results explain why the gains from IT adoption have been so samplespecific, and have tended to be larger among developing economies. For countries that adopted IT from a low starting level of transparency — as has tended to be the case among developing economies - the gains in terms of reduced disagreement have been large. For those that adopted IT while already operating at high levels of transparency, the gains have been much smaller.

To verify this conclusion, we estimate a model that interacts the IT adoption dummy with a categorical variable that splits the sample into three equal categories according to their level of transparency in 1998. We report the results in Table 2, column 10. Gains from IT adoption accrue to the economies that were in the lower third of transparency at the start of the period, whereas those in the group of higher transparency countries see no gains from adopting inflation targeting. Of the 14 countries in the low-transparency bucket, 13 are developing economies. In contrast, of the 15 countries in the high-transparency bucket, 14 are advanced economies.

\section{Conclusion}

We estimate the determinants of disagreement about future inflation among professional forecasters. In a wider and longer panel, we confirm a number of stylized facts from the literature. Disagreement about inflation: (i) increases in the level and volatility of inflation, and

\footnotetext{
${ }^{14}$ Interestingly, the gains from transparency are not limited to central banks operating inflation targeting regimes. In column 8, we limit the sample to the 17 countries that never adopted IT, and find that the strength of the relationship with disagreement is even stronger than in the full sample.
} 
(ii) is counter-cyclical with respect to output, spiking during recessions. We also provide novel evidence that disagreement increases with global uncertainty, proxied by the VIX index.

We then study the effects of the adoption of inflation targeting regimes on the degree of disagreement about future inflation, which has been used as a proxy for the degree of anchoring of inflation expectation. We confirm the existing result that the adoption of an IT regime reduces the degree of disagreement on average, but that this effect is only observed among developing economies, with no significant effect among advanced economies.

Jointly testing the effects of a related treatment variable-the degree of central bank transparency - allows us to reconcile mixed results in the empirical literature on the benefits of IT adoption. First, we show that there is substantial heterogeneity in the degree to which transparency is increased surrounding IT adoption episodes, and that the gains from IT adoption accrue exclusively through increases in transparency. Second, we show that the decreasing returns in the relationship between transparency and disagreement are strong, with gains from transparency accruing mainly to countries that start from a relatively low level of transparency.

Taken together, these findings explain why the gains from IT adoption have been samplespecific in the existing literature, tending to favor developing economies. When adoption has been accompanied by substantial increases in transparency, and from a low initial level of transparency, the gains have been large. In contrast, adoptions that involve little change in transparency, or that are initiated when transparency is already high, have yielded much smaller gains.

Understanding the mechanisms behind the gains from central bank transparency-including their apparent non-linearity-will require additional research. A promising avenue for empirical work involves determining which sub-components of the Dincer \& Eichengreen (2014) index deliver the greatest gains. 


\section{References}

Ball, L.M. and N. Sheridan, 2004. "Does inflation targeting matter?” In The Inflation Targeting Debate, eds. B.S. Bernanke and M. Woodford. National Bureau of Economic Research.

Brito, R.D. and B. Bystedt, 2010. "Inflation targeting in emerging economies: Panel evidence," Journal of Development Economics 91(2): 198-210.

Capistrán, C. and M. Ramos-Francia, 2010. "Does inflation targeting affect the dispersion of inflation expectations?" Journal of Money, Credit and Banking 42(1): 113-34.

Coibion, O. and Y. Gorodnichenko, 2012. "What can survey forecasts tell us about information rigidities?” Journal of Political Economy 120(1): 116-59.

Crowe, C., 2010. "Testing the transparency benefits of inflation targeting," Journal of Monetary Economics 57(2): 226-32.

Crowe, C. and E.E. Meade, 2008. "Central bank independence and transparency: evolution and effectiveness," European Journal of Political Economy 24: 763-77.

Dincer, N. and B. Eichengreen, 2014. "Central bank transparency and independence: update and new measures,” International Journal of Central Banking 10(1): 189-259.

Dovern, J., U. Fritsche, and J. Slacalek, 2012. "Disagreement among forecasters in G7 countries," Review of Economics and Statistics 94(4): 1081-96.

Ehrmann, M., S. Eijffinger, and M. Fratzscher, 2012. "The role of central bank transparency for guiding private sector forecasts," Scandinavian Journal of Economics 114(3): $1018-52$.

Gürkaynak, R., A. Levin, and E. Swanson, 2010. "Does inflation targeting anchor long-run inflation expectations? Evidence from the U.S., U.K., and Sweden," Journal of the European Economic Association 8(6): 1208-42.

Gonçalves, C.E. and J.M. Salles, 2008. "Inflation targeting in emerging economies: what do the data say?" Journal of Development Economics 85(1): 312-8.

Johnson, D. 2002. "The effect of inflation targeting on the behavior of expected inflation: evidence from an 11 country panel," Journal of Monetary Economics 49(8): 1521-38. 
Kumar, S., H. Afrouzi, O. Coibion and Y. Gorodnichenko, 2015. "Inflation targeting does not anchor inflation expectations: Evidence from firms in New Zealand," Brookings Papers on Economic Activity Fall: 151-225.

Mankiw, N.G., R. Reis, and J. Wolfers, 2004. "Disagreement about inflation expectations," NBER Macroeconomics Annual 2003 18: 209-48.

Mishkin, F.S., 2000. "Inflation targeting in emerging-market countries," American Economic Review 90(2): 105-9, May.

Morris, S. and H.S. Shin, 2002. "Social value of public information," American Economic Review 92(5): 1521-34.

Ozturk, E. and X.S. Sheng, 2017. "Measuring global and country-specific uncertainty," Journal of International Money and Finance, In press.

Siklos, P., 2013. "Sources of disagreement in inflation forecasts: An international empirical investigation," Journal of International Economics 90(1): 218-31.

Sims, C., 2003. "Implications of rational inattention," Journal of Monetary Economics 50(3): 665-90.

Stock, J. and M. Watson, 2007. "Why has U.S. inflation become harder to forecast?" Journal of Monetary, Credit and Banking 39(Sup. 1): 3-33.

Van der Cruijsen, C., S. Eijffinger, and L. Hoogduin, 2010. "Optimal central bank transparency," Journal of International Money and Finance 29(8): 1482-507.

Vega, M. and D. Winkelried, 2005. "Inflation targeting and inflation behavior: a successful story?” International Journal of Central Banking 1(3): 153-75.

Walsh, C.E., 2007. “Optimal economic transparency,” International Journal of Central Banking 3(1): 5-36. 
APPENDIX Table A1. Estimates for the determinants of disagreement about inflation one year ahead (with time fixed effects)

\begin{tabular}{|c|c|c|c|c|c|c|c|c|c|c|}
\hline & $(1)$ & $(2)$ & (3) & $(4)$ & $(5)$ & $(6)$ & $(7)$ & $(8)$ & (9) & $(10)$ \\
\hline Inflation rate & $\begin{array}{c}5.69 * * * \\
(0.71)\end{array}$ & $\begin{array}{c}5.56^{* * * *} \\
(0.72)\end{array}$ & $\begin{array}{c}5.43 * * * \\
(0.73)\end{array}$ & $\begin{array}{c}4.31^{* * *} \\
(0.48)\end{array}$ & $\begin{array}{c}4.40 * * * \\
(0.84)\end{array}$ & $\begin{array}{c}4.32 * * * \\
(0.81)\end{array}$ & $\begin{array}{c}4.40 * * * \\
(0.76)\end{array}$ & $\begin{array}{c}8.03 * * * \\
(1.88)\end{array}$ & $\begin{array}{c}4.41 * * * \\
(0.76)\end{array}$ & $\begin{array}{c}3.99 * * * \\
(0.54)\end{array}$ \\
\hline Volatility of inflation & $\begin{array}{c}2.10 \\
(1.41)\end{array}$ & $\begin{array}{c}2.11 \\
(1.40)\end{array}$ & $\begin{array}{c}2.12 \\
(1.39)\end{array}$ & $\begin{array}{c}8.80^{* * * *} \\
(1.83)\end{array}$ & $\begin{array}{c}9.53 * * * \\
(1.91)\end{array}$ & $\begin{array}{c}9.16^{* * * *} \\
(1.96)\end{array}$ & $\begin{array}{c}9.06^{* * * *} \\
(1.92)\end{array}$ & $\begin{array}{c}50.63^{* * *} \\
(3.81)\end{array}$ & $\begin{array}{c}9.06^{* * *} \\
(1.92)\end{array}$ & $\begin{array}{c}8.83 * * * \\
(1.92)\end{array}$ \\
\hline Output gap & $\begin{array}{c}-4.60 * * * \\
(1.30)\end{array}$ & $\begin{array}{c}-4.68 * * * \\
(1.31)\end{array}$ & $\begin{array}{c}-4.72 * * * \\
(1.32)\end{array}$ & $\begin{array}{l}-3.80 * \\
(1.98)\end{array}$ & $\begin{array}{c}-3.66^{* *} \\
(1.66)\end{array}$ & $\begin{array}{c}-3.81 * * \\
(1.67)\end{array}$ & $\begin{array}{c}-3.62^{* *} \\
(1.73)\end{array}$ & $\begin{array}{c}-3.37 * * * \\
(0.58)\end{array}$ & $\begin{array}{c}-3.62 * * \\
(1.72)\end{array}$ & $\begin{array}{c}-4.63 * * \\
(2.22)\end{array}$ \\
\hline Recession & $\begin{array}{c}20.76^{* * *} \\
(6.98)\end{array}$ & $\begin{array}{c}19.62 * * * \\
(7.00)\end{array}$ & $\begin{array}{c}19.94 * * * \\
(6.93)\end{array}$ & $\begin{array}{c}17.31 * * * \\
(5.81)\end{array}$ & $\begin{array}{c}16.24 * * * \\
(5.53)\end{array}$ & $\begin{array}{c}15.83 * * * \\
(5.30)\end{array}$ & $\begin{array}{c}14.35 * * * \\
(5.05)\end{array}$ & $\begin{array}{c}21.73 \\
(13.72)\end{array}$ & $\begin{array}{c}14.35 * * * \\
(5.11)\end{array}$ & $\begin{array}{c}15.99 * * * \\
(5.45)\end{array}$ \\
\hline IT (12-mth lag) & & $\begin{array}{c}-14.03 * * \\
(6.90)\end{array}$ & $\begin{array}{l}-1.96 \\
(8.12)\end{array}$ & $\begin{array}{c}6.10 \\
(11.44)\end{array}$ & & & & & $\begin{array}{c}-1.43 \\
(11.07)\end{array}$ & \\
\hline IT \& EMDE (12-mth lag) & & & $\begin{array}{c}-23.39 * \\
(12.85)\end{array}$ & $\begin{array}{c}-21.82 * \\
(12.49)\end{array}$ & & & & & $\begin{array}{c}1.98 \\
(18.60)\end{array}$ & \\
\hline Central bank transparency (12-mth lag) & & & & & $\begin{array}{l}-3.20 \\
(4.14)\end{array}$ & $\begin{array}{c}1.51 \\
(3.33)\end{array}$ & $\begin{array}{c}-18.54 * * \\
(8.14)\end{array}$ & $\begin{array}{c}-40.11^{*} \\
(21.72)\end{array}$ & $\begin{array}{c}-18.63^{*} \\
(9.27)\end{array}$ & \\
\hline Central bank transparency \& EMDE (12-mth lag) & & & & & & $\begin{array}{c}-7.23 * * * \\
(2.37)\end{array}$ & & & & \\
\hline Central bank transparency squared (12-mth lag) & & & & & & & $\begin{array}{c}1.00 * * * \\
(0.31)\end{array}$ & $\begin{array}{c}2.50 * * \\
(0.89)\end{array}$ & $\begin{array}{c}1.00 * * * \\
(0.36)\end{array}$ & \\
\hline IT \& Low transparency (12-mth lag) & & & & & & & & & & $\begin{array}{c}-22.33 * * * \\
(6.34)\end{array}$ \\
\hline IT \& Mid transparency (12-mth lag) & & & & & & & & & & $\begin{array}{c}0.15 \\
(12.39)\end{array}$ \\
\hline IT \& High transparency (12-mth lag) & & & & & & & & & & $\begin{array}{l}-6.14 \\
(8.79)\end{array}$ \\
\hline Observations & 9,879 & 9,879 & 9,879 & 7,697 & 7,479 & 7,479 & 7,479 & 2,632 & 7,479 & 7,503 \\
\hline R-squared & 0.39 & 0.39 & 0.39 & 0.38 & 0.41 & 0.41 & 0.42 & 0.34 & 0.42 & 0.38 \\
\hline Number of ifscode & 44 & 44 & 44 & 44 & 44 & 44 & 44 & 17 & 44 & 44 \\
\hline Start & $1989 \mathrm{ml} 0$ & $1989 \mathrm{ml} 0$ & $1989 \mathrm{ml} 0$ & 1999ml & $1999 \mathrm{ml}$ & 1999ml & $1999 \mathrm{ml}$ & $1999 \mathrm{ml}$ & 1999ml & $1999 \mathrm{ml}$ \\
\hline $\begin{array}{l}\text { End } \\
\text { IT countries }\end{array}$ & $2016 \mathrm{ml} 2$ & $2016 \mathrm{ml} 2$ & $2016 \mathrm{ml} 2$ & $2015 \mathrm{ml} 2$ & $2015 \mathrm{ml} 2$ & $2015 \mathrm{~m} 12$ & $2015 \mathrm{ml} 2$ & $\begin{array}{c}2015 \mathrm{~m} 12 \\
\text { No }\end{array}$ & $2015 \mathrm{ml} 2$ & $2015 \mathrm{ml} 2$ \\
\hline
\end{tabular}

Notes: All specifications include country and time fixed effects. Disagreement variable has been truncated at $99^{\text {th }}$ percentile $($ see text). White $(1980)$ heteroskedasticity-consistent robust standard errors in parentheses. $* * * \mathrm{p}<0.01, * * \mathrm{p}<0.05, * \mathrm{p}<0$. 